\title{
Retorika Polisi Lalu Lintas di Kota Sampang
}

\author{
Kusyairi $^{1}$, Hendry Budiman ${ }^{2}$, Nur Hayati ${ }^{3}$ \\ Universitas Madura, Madura \\ ${ }^{1}$ kusyairi@unira.ac.id, ${ }^{2}$ h3ndr3y@unira.ac.id, ${ }^{3}$ noe92@yahoo.com
}

\begin{abstract}
The use of rhetoric occurs to the Traffic Police in carrying out their duties to give people an understanding of the importance of good traffic awareness. This research is an attempt to describe how Traffic Police rhetoric in the City of Sampang compiling words and conveying ideas as an effective effort in speaking. This type of research is a descriptive study with a qualitative approach. Based on the results of the study, it revealed that the wording presented by Sampang Traffic Polices when conducting traffic operations has used the right and effective words. This is demonstrated by the way Sampang Police Traffic greets motorists who violate traffic using polite and decisive questions. They told them about violations, cracked down, and charged traffic violators. In addition, they convey ideas effectively to motorists appropriately and advised people by giving direction, giving instructions in accordance with what was violated so that the public understood what was conveyed by the police.
\end{abstract}

Keywords: rhetoric, traffic police, lacquer

Abstrak : Penggunaan retorika terjadi pada Polisi Lalu Lintas dalam melaksanakan tugas memanfaatkan retorika untuk memberikan pemahaman kepada masyarakat tentang pentingnya kesadaran berlalu lintas yang baik. Penelitian ini merupakan suatu upaya untuk mendeskripsikan retorika Polisi Lalu Lintas di Kota Sampang dalam menyusun kata-kata yang efektif dalam bertutur dan mendeskripsikan cara Polisi Lalu Lintas di Kota Sampang dalam menyampaikan gagasan sebagai usaha efektif dalam bertutur. Jenis penelitian yang digunakan adalah penelitian deskriptif ekplanatif dengan pendekatan kualitatif. Berdasarkan hasil penelitian, susunan kata yang disampaikan Polantas Sampang saat melakukan operasi lalu lintas sudah menggunakan kata yang tepat dan efektif. Hal ini ditujukkan dengan cara Polantas Sampang menyapa pengendara yang melanggar lalu lintas menggunakan pertanyaan yang sopan dan tegas. Tuturannya memberi tahu pelanggaran, menindak, serta mendakwa para pelanggar lalu lintas. Selain itu, Polantas di Kota Sampang menyampaikan gagasan secara efektif kepada pengendara dengan tepat. Mereka menasehati dengan cara memberi arahan, memberi petunjuk yang sesuai dengan apa yang dilanggar supaya masyarakat paham apa yang disampaikan oleh aparat kepolisian.

Kata kunci: retorika, polisi lalu lintas, sampang

Sitasi Artikel:

Kusyairi, K., Budiman, H., \& Hayati, N. (2020). Retorika Polisi Lalu Lintas di Kota Sampang. Disastra: Jurnal Pendidikan Bahasa dan Sastra Indonesia, 2(2), 97-109. doi:http://dx.doi.org/10.29300/disastra.v2i2.2934 


\section{Pendahuluan}

Penggunaan bahasa sebagai media dalam proses berinteraksi memang sangat efektif, mengingat salah satu fungsi utamanya dari bahasa adalah sebagai alat komunikasi yang dapat menjalin kerja sama dengan baik. (Kusyairi, 2020: 1260). Kota Sampang merupakan kota kecil, tetapi seiring dengan bertambahnya volume kendaraan membuat permasalahan lalu lintas di kota Sampang ini makin banyak. Untuk menyelesaikan permasalahan tersebut, tentu tidak terlepas dari peran dan tanggung jawab dari Polisi Lalu Lintas (Polantas) di Kota Sampang.

Setiap kali terdapat kecelakaan lalu lintas, akan berhubungan dengan Polantas. Hal ini membuktikan bahwa keberadaan Polantas didambakan masyarakat. Belum lagi permasalahan lain yang tentunya berkaitan dengan keberadaan Polantas di Kota Sampang ini, misalnya kemacetan lalu lintas, pohon tumbang di jalan, hingga ibuibu minta tolong dibantu karena mobilnya mogok di jalan. Itulah beberapa permasalahan yang sering dihadapi oleh Polantas.

Polantas harus lebih professional, lebih dekat, dan lekat di hati masyarakat dalam melayani, melindungi, serta mengayomi warganya. Oleh karena itu, Polantas harus menguasai retorika atau seni berbicara dalam mengucapkan kata atau kalimat kepada seseorang maupun sekelompok orang untuk mencapai suatu tujuan tertentu, misalnya memberikan informasi kepada pelanggar lalu lintas atau pengguna jalan. Hal ini sejalan dengan fungsi bahasa itu sendiri sebagai sarana untuk berhubungan dengan masyarakat atau individu lainnya (Eliya, 2018).

Retorika (dari bahasa Yunani) adalah sebuah teknik pembujuk-rayuan secara persuasif untuk menghasilkan bujukan melalui karakter pembicara, emosional, atau argumen (logo). Aristoteles mencetuskan dalam sebuah dialog sebelum The Rhetoric dengan judul 'Grullos' atau Plato menulis 'Gorgias', secara umum ialah seni manipulatif atau teknik persuasi politik yang bersifat transaksional dengan menggunakan lambang untuk mengidentifikasi pembicara dengan pendengar melalui pidato, persuader, dan yang dipersuasi untuk bekerja sama dalam merumuskan nilai, kepercayaan, dan pengharapan mereka. (Dori, Wuwur Hendrik, 1991: 122).

Definisi lain tentang retorika adalah suatu gaya/seni berbicara yang dicapai berdasarkan bakat alami (talenta) dan keterampilan teknis (I Gusti Ngurah Oka, 1990: 68). Dewasa ini retorika diartikan sebagai seni berbicara yang dipergunakan dalam proses komunikasi antarmanusia. Kesenian berbicara bukan hanya berarti berbicara secara lancar tanpa jalan pikiran yang jelas dan tanpa isi, melainkan suatu kemampuan untuk berbicara dan berpidato secara singkat, jelas, padat, dan mengesankan. Retorika modern mencakup ingatan yang kuat, daya kreasi, dan fantasi yang tinggi, teknik pengungkapan yang tepat, dan daya pembuktian serta penilaian yang tepat. Ber-retorika juga harus bertanggung jawab atas pemilihan kata dan nada bicara yang sesuai dengan tujuan, ruang, waktu, situasi, dan siapa lawan bicara yang dihadapi 


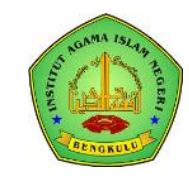

Titik tolak retorika adalah berbicara.

Berbicara berarti mengucapkan kata atau kalimat kepada seseorang atau sekelompok orang untuk mencapai suatu tujuan tertentu (misalnya memberikan informasi atau memberi informasi). Berbicara adalah salah satu kemampuan khusus pada manusia. Oleh karena itu, pembicaraan sesuai umur bangsa manusia. Bahasa dan pembicaraan ini muncul ketika manusia mengucapkan dan menyampaikan pikirannya kepada manusia lain. Kebiasaan-kebiasaan yang perlu diperbaiki yang telah membudaya bagi suatu bangsa, termasuk bangsa Indonesia, dapat diungkapkan melalui bahasa (Bustomi, 2019). Retorika modern adalah gabungan yang serasa antara pengetahuan, pikiran, kesenian, dan kesanggupan berbicara.

Kusyairi (2016:92) menjelaskan retorika merupakan suatu disiplin ilmu yang masih jarang diaplikasikan dalam percakapan sehari-hari sebab istilah tersebut memiliki beberapa definisi yang kontroversial, artinya tidak jelas maksud dari bahasa atau kata yang digunakan. Banyak orang yang mendefinisikan retorika sebagai ilmu silat lidah. Definisi tersebut didasarkan pada sejarah pengaplikasikan retorika pada masa lalu.

Berdasarkan fakta di lapangan yang didokumentasikan dalam bentuk rekaman audio visual, dapat ditemukan cara Polantas menyusun kata-kata sebagai usaha efektif bertutur dalam ungkapan atau gagasangagasan seorang Polantas Kota Sampang terhadap salah satu pengendara sepeda motor yang melanggar peraturan lalu lintas. Adapun kutipan hasil rekamannya sebagai berikut.

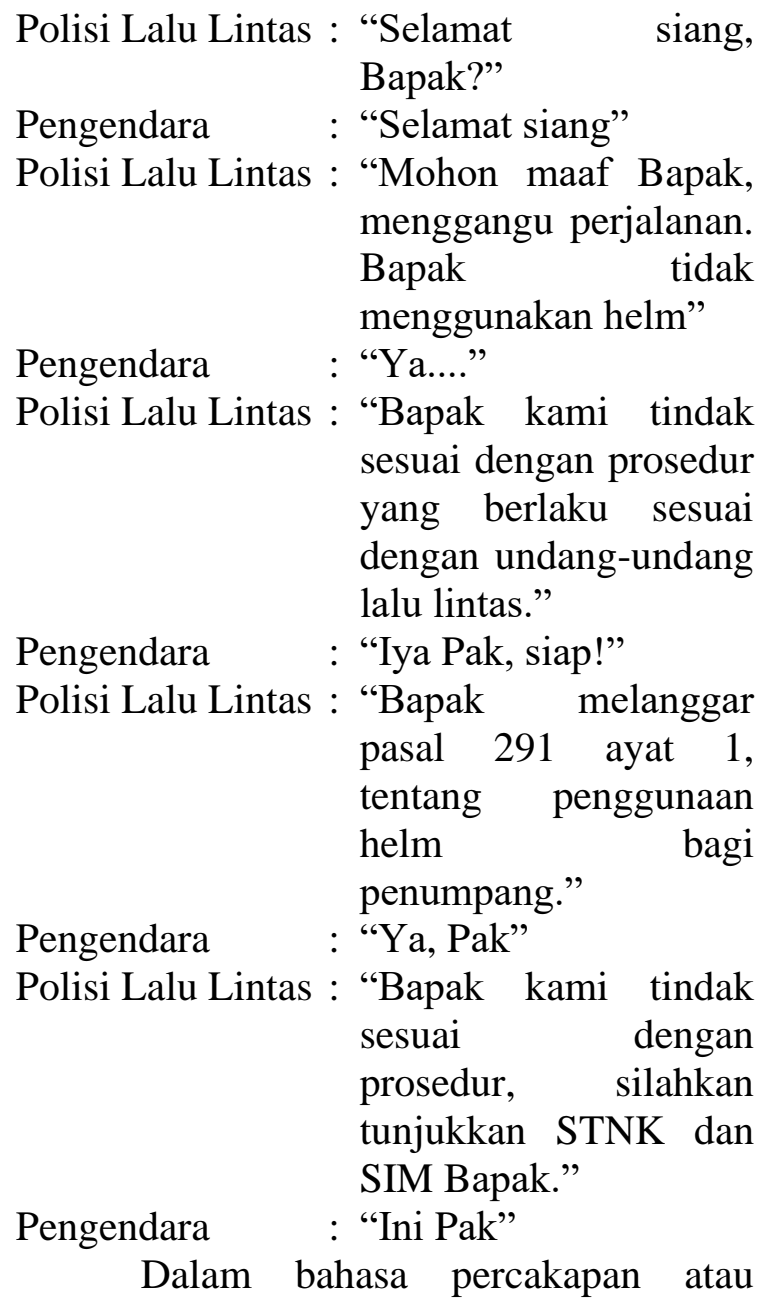
bahasa populer, retorika berarti pada tempat dan waktu yang tepat, cara yang lebih efektif, ucapan kata-kata yang tepat, benar, dan mengesankan. Hal ini berarti orang harus dapat berbicara jelas, singkat, dan efektif. Jelas supaya mudah dimengerti; singkat untuk menghemat waktu dan sebagai tanda kepintaran; dan efektif karena apa gunanya berbicara kalau tidak membawa efek. Dalam konteks ini sebuah pepatah Cina mengatakan, "Orang yang menembak banyak, belum tentu seorang penembak yang baik. Orang yang berbicara banyak tidak selalu berarti seorang yang pandai bicara." Keterampilan dan kesanggupan untuk menguasai seni 
berbicara ini dapat dicapai dengan mencontoh para rektor atau tokoh-tokoh yang terkenal dengan mempelajari dan mempergunakan hukum-hukum retorika dan dengan melakukan latihan yang teratur. Dalam seni berbicara dituntut juga penguasaan bahan dan pengungkapan yang tepat melalui bahasa.

\section{Metode Penelitian}

Penelitian adalah suatu proses mencari sesuatu secara sistematik dalam waktu yang lama dengan menggunakan metode ilmiah yang aktual disusun suatu desain penelitian yang sesuai dengan kondisi yang seimbang, dalam, dan dangkalnya penelitian yang dikerjakan (Hadi, 1989: 8). Metode yang digunakan dalam penelitian ini adalah deskriptif ekplanatif dengan pendekatan kualitatif. Penelitian deskriptif eksplanatif tidak hanya mengambarkan realitas yang diteliti, tetapi penelitian ini sampai pada interpretasi.

Dalam penelitian ini konsep-konsep yang dipilih bukan untuk diuji, tetapi dipergunakan untuk menginterpretasikan hakikat suatu gejala atau realitas yang diteliti (Sugiyono, 1998: 24)

Perlunya desain penelitian sebagaimana dimaksud Arikunto adalah sebagai langkah awal dari seseorang yang akan mengadakan penelitian. Desain penelitian itu juga dikenal dengan sebutan rancangan penelitian. Desain penelitian itu sendiri menurut Arikunto adalah rencana atau rancangan yang dibuat oleh peneliti sebagai ancar-ancar kegiatan yang akan dilaksanakan (Arikunto, 2002: 10).

Data yang dikumpulkan dalam suatu penelitian haruslah relevan dengan permasalahannnya. Sumber data yang dipergunakan dalam penelitian kualitatif ada tiga macam, yaitu seseorang (informan), peristiwa atau kejadiankejadian, dan dokumen atau suatu benda yang dapat dijadikan sumber untuk mendapatkan data-data yang diperlukan (Faisal Sanafiah, 1989:44).

Adapun teknik pengumpulan data yang dilakukan sebagai berikut.

1) Observasi, yaitu untuk mengamati secara langsung objek yang diteliti. Dalam hal ini yang menjadi objek adalah Polisi Lalu Lintas dan pengendara. Kegiatan observasi ini peneliti berbaur secara langsung pada saat Polisi Lalu Lintas sedang menindak pengendara yang melanggar lalu lintas.

Tabel 1:Data Kegiatan Pengamatan

\begin{tabular}{|c|l|}
\hline No & \multicolumn{1}{|c|}{ Kegiatan yang diamati } \\
\hline 1. & $\begin{array}{l}\text { Kegiatan Polantas yang satu } \\
\text { dengan yang lain } \\
\text { Tuturan yang digunakan Polantas } \\
\text { dan pengendara } \\
\text { Gagasan yang terdapat dalam } \\
\text { tuturan Polantas dan pengendara }\end{array}$ \\
\hline
\end{tabular}

2) Perekaman dan pencatatan, yaitu merekam dan mencatat tuturan yang didengarkan dari percakapan antara Polisi Lalu Lintas dengan pengendara. Hasil rekaman itu ditranskripsikan ke dalam bentuk tulisan yang akan dijadikan bahan untuk dianalisis. Data tersebut terbagi dalam beberapa percakapan atau beberapa tuturan dalam tape recorder atau rekaman melalui HP. Dari transkrip-transkrip tersebut akan dicari gagasan dalam 
Volume 2, Nomor 2, Juli 2020 ISSN 2655-3031 (P), 2655-7851 (O)

percakapan antara Polisi Lalu Lintas dengan pengendara sebagai cara efektif bertutur.

Sumber data yang digunakan dalam penelitian ini diharapkan mampu menyediakan informasi yang diperlukan antara lain sebagai berikut.

1. Data primer adalah data yang diperoleh dari para sumber yang langsung berhubungan dengan penelitian dan mampu memberikan informasi. Dalam hal ini Polisi Lalu Lintas Polres Sampang yang sedang menindak pelanggaran lalu lintas.

2. Data sekunder adalah data yang telah lebih dahulu dikumpulkan dan dilaporkan oleh orang di luar peneliti, berupa hasil penelitian kepustakaan yang dilakukan melalui studi literatur buku-buku ilmiah yang berhubungan dengan masalah yang dibahas.

Tabel 2: Data Informan Polisi Lalu Lintas di Kota Sampang

\begin{tabular}{|c|l|}
\hline No. & \multicolumn{1}{|c|}{ Nama } \\
\hline 1 & Briptu Dimas Pratimy \\
2 & Brigadir Putra Guntur H. \\
3 & Brigadir Budi C.K. \\
\hline
\end{tabular}

\section{Hasil dan Pembahasan}

Polisi Lalu Lintas di Kota Sampang dalam melakukan razia pengendara menggunakan diksi dalam tuturannya (berbicara). Penyusunan kosakata dimaksudkan supaya dalam melakukan razia, khususnya dalam tindakan pencegahan, mendapat respon yang positif dari pelanggar lalu lintas. Tuturan tersebut mengandung tujuan dan juga merupakan retorika.
Retorika adalah seni berkomunikasi secara lisan yang dilakukan oleh seseorang kepada sejumlah orang secara langsung bertatap muka. Retorika menitikberatkan pada aspek berbicara. Berbicara berarti mengucapkan kata atau kalimat kepada seseorang atau sekelompok orang untuk mencapai suatu tujuan tertentu. Berbicara dapat meningkatkan kualitas eksistensi (keberadaan) di tengah-tengah orang lain. Berbicara bukanlah sekadar berbicara, tetapi harus menarik (atraktif), bernilai informasi (informatif), menghibur (rekreatif), dan berpengaruh (persuasif). Dengan kata lain, manusia mesti berbicara berdasarkan seni berbicara yang dikenal dengan istilah retorika.

Retorika berarti kesenian untuk berbicara baik, yang dicapai berdasarkan bakat alam (talenta), dan keterampilan teknis. Retorika juga sering diartikan sebagai kesenian untuk berbicara baik yang dipergunakan dalam proses komunikasi antarmanusia. Kesenian berbicara ini bukan hanya berarti berbicara lancar tanpa jalan pikiran yang jelas dan tanpa isi, melainkan suatu kemampuan untuk berbicara secara singkat, padat, dan mengesankan. Retorika modern mencakup ingatan yang kuat, daya kreasi, dan fantasi yang tinggi, teknik pengungkapan yang tepat, dan daya pembuktian serta penilaian yang tepat. Retorika modern adalah gabungan yang serasi antara pengetahuan, pikiran, kesenian, dan kesanggupan berbicara dan juga harus dapat dipertanggungjawabkan disertai pemilihan kata dan nada bicara yang sesuai dengan tujuan, ruang, waktu, situasi, dan siapa lawan bicara yang dihadapi. Dalam bahasa percakapan atau 
bahasa populer, retorika berarti pada tempat yang tepat, pada waktu yang tepat, atas cara yang lebih efektif, mengucapkan kata-kata yang tepat, benar, dan mengesankan. Hal ini menunjukkan bahwa setiap orang harus berbicara jelas, singkat, dan efektif.

Tujuan retorika adalah persuasi, yang dimaksudkan dalam persuasi dalam hubungan ini adalah yakinnya pendengar akan kebenaran gagasan hal yang dibicarakan pembicara. Artinya, tujuan retorika adalah membina saling pengertian yang mengembangkan kerjasama dalam menumbuhkan kedamaian dalam kehidupan bermasyarakat lewat kegiatan bertutur.

Penyajian data temuan dalam bentuk tabel akan diuraikan dalam bentuk deskripsi kualitatif, yaitu sebagai berikut.

\section{Data Percakapan Nomor 1}

Retorika pada percakapan pertama, melihat cara polisi menyusun kata-kata sebagai percakapan dengan pengendara. Kata-kata yang disusun oleh polisi dalam tindakannya bertutur dengan para pengendara pada saat melakukan operasi lalu lintas memang harus diperhatikan diksinya. Pilihan kata yang tepat dalam berbicara berpengaruh terhadap keberadaan serta keadaan yang terjadi selanjutnya. Intinya, dalam berbicara harus dapat meningkatkan kualitas eksistensi (keberadaan) di tengah-tengah orang lain, bukan sekadar berbicara, melainkan berbicara dengn menarik (atraktif), bernilai informasi (informatif), menghibur (rekreatif), dan berpengaruh (persuasif). Hal ini dapat kita lihat dalam percakapan Polisi Lalu Lintas Sampang, sebagai berikut.

\section{1) Percakapan 1}

Polisi Lalu Lintas : "Selamat siang pak?"

Dari segi penyusunan kata sudah tepat ialah tetap "Selamat siang, Bapak?" yang memiliki makna menyatakan sapaan karena waktu terjadinya kejadian pada siang hari. Pendeskripsiannya ialah cara menyapa yang umum.

\section{2) Percakapan 2}

Polisi Lalu Lintas : "Mohon maaf pak, menggangu perjalanan. Bapak tidak menggunakan helm"

Dari segi penyusunan kata yang tepat ialah "Saya mohon maaf karena memberhentikan Bapak, sehingga mengganggu perjalanannya. Bapak tidak menggunakan helm?" yang memiliki makna memberhentikan yang dimaksud adalah hal yang mengganggu. Pendeskripsiannya ialah keadaan seperti ini sudah sering kita lihat. Digunakan kata mengganggu karena tindakan memberhentikan di jalan dianggap menganggu pengendara yang bepergian karena ada suatu urusan, terlebih urusan penting sehingga menuntut untuk mengejar waktu.

\section{3) Percakapan 3}

Polisi Lalu Lintas : "Bapak kami tindak sesuai dengan prosedur yang berlaku sesuai dengan undangundang lalu lintas."

Dari segi penyusunan kata yang tepat ialah "Bapak akan kami tindak sesuai dengan kesalahan yang Bapak lakukan" yang memiliki makna macam tindak kesalahan akan ditindak berdasarkan undang-undang lalu lintas. Maksudnya akan 
ditindak berdasarkan tingkat kesalahan yang ada. Tingkat mengenai kesalahan sudah diatur dalam undang-undang lalu lintas (termasuk pasal, sanksi dll). Pendeskripsiannya ialah Polisi langsung mengatakan akan segera menindaklanjuti sesuai dengan undang-undang lalu lintas, maksudnya adalah kesalahan yang dilakukan pengendara. Kesalahan tadi tidak menggunakan helm dari pemboncengnya.

\section{4) Percakapan 4}

Polisi Lalu Lintas: "Bapak melanggar pasal 291 ayat 1, tentang penggunaan helm bagi penumpang."

Dari segi penyusunan kata yang tepat ialah "Karena penumpang tidak menggunakan helm, maka bapak melanggar pasal 291 ayat 1." yang memiliki makna kata penumpang disini kurang jelas karena maksudnya adalah pengendara (pengemudi) Pendeskripsiannya ialah Pasal 291 ayat 1 mengatur penggunaan helm bagi penumpang. Kata penumpang di sini mempunyai makna yang tidak jelas. Penumpang maksudnya pengemudi atau pembonceng. Berdasarkan perkataan polisi sebelumnya mengarah pada pengemudi.

\section{5) Percakapan 5}

Polisi Lalu Lintas : "Bapak kami tindak sesuai dengan prosedur, silahkan tunjukkan STNK dan SIM bapak."

Dari segi penyusunan kata yang tepat ialah "Silakan tunjukkan STNK dan SIMnya sebagai kelengkapan berkendara selain helm untuk dicek." yang memiliki makna selain itu sebagai jaminan kalau ditilang. Lebih tepat menggunakan kata tunjukkan daripada mengeluarkan.

Pendeskripsiannya menunjukkan berarti harus ada bukti konkretnya, berupa STNK dan SIM. Kalimat "Bapak kami tindak sesuai dengan prosedur" tidak usah diucapkan lagi karena sudah diucapkan sebelumnya.

6) Percakapan 6

Polisi Lalu Lintas : "Mari Bapak ikut saya."

Dari segi penyusunan kata yang tepat ialah "Mari Bapak ikut Saya ke ........" yang memiliki makna seharusnya lebih jelas mengikuti kemana?. Apa ke Pos Lantas atau Mobil Polantas dsb.

Pendeskripsiannya keterangan tempat harus disertakan untuk memperjelas arah dan tujuannya. Misalnya, ke Pos Lantas atau ke Mobil Patroli, dsb.

\section{7) Percakapan 7}

Polisi Lalu Lintas : "Bapak bisa menghadiri sidang di pengadilan tanggal 9 Oktober 2011 jam 9 pagi."

Dari segi penyusunan kata yang tepat ialah "Karena Bapak melanggar peraturan lalu lintas, maka Bapak akan ditiang. Untuk proses selanjutnya bisa diproses di pengadilan." yang memiliki makna oleh karena itu, Bapak diharap menghadiri sidang di Pengadilan Negeri Sampang tanggal 9 Oktober 2011 jam 09.00 WIB.

Pendeskripsiannya maksudnya pengendara diharap menghadiri sidang untuk proses lebih lanjut (karena sudah ditilang). Seharusnya Si Polisi memperjelas 
tujuan menghadiri sidang karena sebelumnya belum ada kata positif untuk ditilang.

\section{8) Percakapan 8}

Polisi Lalu Lintas : "Kalau begitu, Bapak saya tilang. Nama Bapak siapa?"

Dari segi penyusunan kata yang tepat, "Kalau begitu, Bapak Saya tilang. Nama Bapak siapa?" yang memiliki makna untuk mengisi kolom identitas pelanggar dalam formulir surat tilang pada bagian nama pelangar.

Hal ini mengidentifikasikan bahwa ada kepastian untuk ditilang karena sudah ditanyakan tentang identitas untuk pengisian surat tilang. Perkataan sebelumnya "untuk menghadiri sidang di pengadilan" tidak usah disebutkan terlebih dahulu.

\section{9) Percakapan 9}

Polisi Lalu Lintas : "Kalau begitu, Bapak bisa hadir di pengadilan.'

Dari segi penyusunan kata "Kalau begitu, Bapak bisa hadir di pengadilan" memiliki makna bahwa pengendara sudah ditilang dan harus menyelesaikan proses selanjutnya, yaitu menghadiri proses sidang di pengadilan atau bisa menitipkan uang denda tanpa harus ke pengadilan.

Pendeskripsiannya ini menunjukkan bahwa ada kepastian untuk ditilang karena sudah ditanyakan tentang identitas untuk pengisian surat tilang. Perkataan "untuk menghadiri sidang di pengadilan" tidak perlu diucapkan karena di awal sudah dikatakan. Hal ini mengindikasikan untuk memberikan pilihan/peluang lagi kepada pelanggar untuk menitipkan uang atau berdamai.

\section{0) Percakapan 10}

Polisi Lalu Lintas : "Saya sita untuk barang buktinya berupa STNK dan ini surat tilang sebagai pengganti STNK sampeyan."

Dari segi penyusunan kata yang tepat adalah "Saya sita STNKnya sebagai jaminan surat tilangnya." yang memiliki makna STNK diambil sementara sebagai jaminan dari surat tilang.

Pendeskripsiannya STNK diambil sementara sebagai jaminan dari surat tilang. STNK akan diperoleh kembali setelah diproses dalam sidang pengadilan.

\section{Data percakapan nomor 2}

Retorika pada percakapan kedua melihat cara polisi menyusun kata-kata sebagai percakapan dengan pengendara yang memiliki kesalahan berlalu lintas. Gaya bahasa yang disusun mampu mempengaruhi sehingga menjadi jaminan kelancaran dalam berkomunikasi sehingga pengendara yang ditindak bersikap kooperatif (bekerja sama tanpa melawan). Hal ini dapat kita lihat dalam percakapan Polisi Lalu Lintas Sampang, yaitu sebagai berikut.

\section{1) Percakapan 1}

\section{Selamat siang Mas?'}

Dari segi penyusunan kata sudah tepat ialah "Selamat siang, Bapak?" yang memiliki makna menyatakan sapaan karena waktu terjadinya kejadian pada siang hari. Pendeskripsiannya ialah cara menyapa yang umum. 
Volume 2, Nomor 2, Juli 2020

ISSN 2655-3031 (P), 2655-7851 (O)

2) Percakapan 2

Polisi Lalu Lintas : "Mohon maaf mengganggu perjalanan, bisa lihat surat-surat kendaraannya?"

Dari segi penyusunan kata yang tepat ialah "Mohon maaf mengganggu perjalanannya. Bisa lihat STNK dan SIMnya " yang memiliki makna memeriksa kelengkapan dalam berkendara yaitu STNK dan SIM selain helm dan kelengkapan alat kendaraan.

Pendeskripsiannya ialah maksud kata surat-surat dalam kalimat ini merujuk pada STNK dan SIM. BPKB merupakan surat kendaraan namun tidak akan dibawa kemana-mana. Cukup diwakili oleh STNK.

\section{3) Percakapan 3}

Polisi Lalu Lintas : "Apa Mas tahu mengapa Saya hentikan!'

Dari segi penyusunan kata yang tepat ialah "Mas sudah tahu, apa sebabnya Saya berhentikan." yang memiliki makna sudah tentu Polisi memberhentikan seorang pengendara yang melanggar peraturan lalu lintas. Tidak mungkin Polisi memberhentikan pengendara yang tidak melanggar. Namun, hal ini juga sering terjadi.

Pendeskripsiannya maksudnya Polisi menanyakan alasan diberhentikan untuk menanyakan kesadaran pengendara atas pelanggaran yang dilakukannya. Dengan begitu Polisi memiliki alasan yang kuat untuk memberhentikan pengendara tersebut.

\section{4) Percakapan 4}

Polisi Lalu Lintas : “Kalau begitu Mas, Saya tindak sesuai dengan prosedur yang berlaku. Kalau begitu, Mas silahkan turun "

Dari segi penyusunan kata yang tepat ialah "Kalau begitu Mas. Saya akan tindak sesuai kesalahan yang telah dilakukan. Silakan turun dari sepeda motornya " yang memiliki makna akan ditindak berdasarkan tingkat kesalahan yang ada. Tingkat mengenai kesalahan sudah diatur dalam undang-undang lalu lintas (termasuk pasal, sanksi dll)." Untuk proses selanjutnya, pelanggar disuruh turun dari kendaraannya.

Pendeskripsiannya ialah Polisi langsung mengatakan akan segera menindaklanjuti sesuai dengan undangundang lalu lintas, maksudnya adalah kesalahan yang dilakukan pengendara. Kesalahan tadi tidak menggunakan helm dari pemboncengnya.

\section{5) Percakapan 5}

Polisi Lalu Lintas : "Sesuai dengan aturan yang berlaku, karena Mas tidak menggunakan helm, Saya tindak dengan undang-undang lalu lintas."

Dari segi penyusunan kata yang tepat ialah "Karena yang membonceng tidak pakai helm, maka termasuk pelanggaran lalu lintas. Oleh karena itu akan diproses sesuai undang-undang lalu lintas" yang memiliki makna segala macam tindak pelanggran ada ketentuannya masing-masing.

Pendeskripsiannya ialah Polisi langsung mengatakan akan segera menindaklanjuti sesuai dengan undangundang lalu lintas. Maksudnya adalah kesalahan yang dilakukan pengendara. 
Kesalahan tadi tidak menggunakan helm dari pemboncengnya.

\section{Data percakapan nomor 3}

Retorika pada percakapan ketiga melihat cara polisi menyusun kata-kata sebagai percakapan dengan pengendara. Kata-kata yang disusun oleh Polisi dalam tindakannya bertutur dengan para pengendara pada saat melakukan operasi lalu lintas memang harus diperhatikan diksinya. Hal ini berarti kesenian untuk berbicara baik, yang dicapai berdasarkan bakat alam (talenta) dan keterampilan teknis. Retorika juga sering diartikan sebagai kesenian untuk berbicara baik, yang dipergunakan dalam proses komunikasi antar manusia. Kesenian berbicara ini bukan hanya berarti berbicara lancar tanpa jalan pikiran yang jelas dan tanpa isi, melainkan suatu kemampuan untuk berbicara secara singkat, padat, dan mengesankan. Retorika modern mencakup ingatan yang kuat, daya kreasi, dan fantasi yang tinggi, teknik pengungkapan yang tepat dan daya pembuktian serta penilaian yang tepat. Retorika modern adalah gabungan yang serasi antara pengetahuan, pikiran, kesenian, dan kesanggupan berbicara. Beretorika juga harus dapat dipertanggungjawabkan disertai pemilihan kata dan nada bicara yang sesuai dengan tujuan, ruang, waktu, situasi, dan siapa lawan bicara yang dihadapi. Dalam bahasa percakapan atau bahasa populer, retorika berarti pada tempat yang tepat, pada waktu yang tepat, atas cara yang lebih efektif, mengucapkan kata-kata yang tepat, benar dan mengesankan. Ini berarti orang harus berbicara jelas, singkat dan efektif.

Hal ini dapat kita lihat dalam percakapan Polisi Lalu Lintas Sampang, yaitu;

\section{1) Percakapan 1 \\ Polisi Lalu Lintas : "Selamat siang Bapak?"}

Dari segi penyusunan kata yang tepat ialah "Selamat siang, Bapak?" yang memiliki makna menyatakan sapaan karena waktu terjadinya kejadian pada siang hari. Pendeskripsiannya ialah cara menyapa yang umum.

\section{2) Percakapan 2}

Polisi Lalu Lintas : "Mohon maaf Bapak, menggangu perjalanan. Bapak tidak menggunakan"

Dari segi penyusunan kata yang tepat ialah "Saya mohon maaf karena memberhentikan Bapak, sehingga mengganggu perjalanannya. Bapak tidak menyalakan lampu di siang hari?" yang memiliki makna memberhentikan yang dimaksud adalah hal yang mengganggu.

Pendeskripsiannya ialah keadaan seperti ini sudah sering kita lihat. Digunakan kata mengganggu karena tindakan memberhentikan di jalan dianggap menganggu pengendara yang bepergian karena ada suatu urusan, terlebih urusan penting sehingga menunutut untuk mengejar waktu.

3) Percakapan 3

Polisi Lalu Lintas : "Bapak kami tindak sesuai dengan prosedur yang berlaku sesuai dengan 
pasal 293 UULLAJ NO. 2 TAHUN 2002."

Dari segi penyusunan kata yang tepat ialah "Bapak akan kami tindak sesuai dengan kesalahan yang Bapak lakukan" yang memiliki makna macam tindak kesalahan akan ditindak berdasarkan undang-undang lalu lintas. Maksudnya akan ditindak berdasarkan tingkat kesalahan yang ada. Tingkat mengenai kesalahan sudah diatur dalam undang-undang lalu lintas (termasuk pasal, sanksi dll).

Pendeskripsiannya ialah Polisi langsung mengatakan akan segera menindaklanjuti sesuai dengan undangundang lalu lintas, maksudnya adalah kesalahan yang dilakukan pengendara. Kesalahan tadi tidak menggunakan helm dari pemboncengnya. pengemudi.

\section{4) Percakapan 4}

Polisi Lalu Lintas : "Bapak kami tindak sesuai dengan prosedur, silahkan tunjukkan STNK dan SIM bapak.”

Dari segi penyusunan kata yang tepat ialah "Silakan tunjukkan STNK dan SIMnya sebagai kelengkapan berkendara selain helm untuk dicek." yang memiliki makna selain itu sebagai jaminan kalau ditilang. Lebih tepat menggunakan kata tunjukkan daripada mengeluarkan.

Pendeskripsiannya menunjukkan berarti harus ada bukti konkretnya, berupa STNK dan SIM. Kalimat "Bapak kami tindak sesuai dengan prosedur" tidak usah diucapkan lagi karena sudah diucapkan sebelumnya.

\section{5) Percakapan 5}

Polisi Lalu Lintas : "Mari Bapak ikut saya."

Dari segi penyusunan kata yang tepat ialah "Mari Bapak ikut Saya ke ........". yang memiliki makna seharusnya lebih jelas mengikuti kemana?. Apa ke Pos Lantas atau Mobil Polantas dsb.

Pendeskripsian keterangan tempat harus disertakan untuk memperjelas arah dan tujuannya. Misalnya, ke Pos Lantas atau ke Mobil Patroli, dsb.

6) Percakapan 6

Polisi Lalu Lintas : "Kalau begitu, Bapak saya tilang. Nama Bapak siapa?", Percakapan Polisi Lalu Lintas : "Bapak Heri, alamat di mana?" , Percakapan Polisi Lalu Lintas : "Bapak Heri umur berapa?”, dan Percakapan Polisi Lalu Lintas : "Pekerjaan?"

Dari segi penyusunan kata yang tepat "Kalau begitu, Bapak Saya tilang. Silahkan sebutkan identitasnya, sesuai yang saya tanyakan ." yang memiliki makna untuk mengisi kolom identitas pelanggar dalam formulir surat tiang, meliputi; nama, alamat, umur, pekerjaan.

Pendeskripsiannya hal ini mengidentifikasikan bahwa ada kepastian untuk ditilang karena sudah ditanyakan tentang identitas untuk pengisian surat tilang. Perkataan sebelumnya "untuk menghadiri siding di pengadilan" tidak usah disebutkan terlebih dahulu. 
7) Percakapan 7

Polisi Lalu Lintas : "Kalau begitu, Bapak bisa hadir di pengadilan"

Dari segi penyusunan kata yang tepat "Saya tegaskan sekali Bapak. Apakah Bapak bisa hadir di pengadilan?" yang memiliki makna untuk menegaskan saja karena di awal sudah ditanyakan hal yang sama.

Seharusnya pernyataan seperti ini tidak usah dikatakan lagi karena di awal sudah dikatakan. Hal ini mengindikasikan untuk memberikan pilihan/peluang lagi kepada pelanggar untuk menitipkan uang atau berdamai.

\section{Simpulan}

Polisi Lalu Lintas di Kota Sampang menyampaikan kata-kata secara tepat dan efektif kepada pengendara. Para Polantas menggunakan kata yang tepat dan selaras sehingga menjadi efektif dalam melaksanakan tugas, yaitu bertanya secara sopan dan tegas serta menunjukkan pelanggaran, menindak, dan mendakwa. Hal ini berdampak positif bagi pengendara untuk mematuhi peraturan lalu lintas.

Selain itu, Polisi Lalu Lintas di Kota Sampang menyampaikan gagasan secara efektif kepada pengendara dan dilakukan dengan tepat, yaitu dengan cara menasehati memberi arahan, memberi petunjuk yang sesuai dengan apa yang dilanggar biar masyarakat paham apa yang disampaikan oleh aparat kepolisian.

\section{Daftar Pustaka}

Bustomi, B. (2019). WAJAH BANGSA DALAM CERMIN BUDAYA BERBAHASA. Disastra: Jurnal Pendidikan Bahasa dan Sastra Indonesia, 1(2), 103-113. doi:http://dx.doi.org/10.29300/disast ra.v1i2.2054

Dori, Wuwur Hendrik, 1991. Retorika, Terampil berpidato, berdiskusi, berargumentasi, bernegoisasi, Kanisius, Yogyakarta.

Eliya, Ixsir. 2018. "Fungsi Pilihan Kode Tutur dalam Wacana Keagamaan: Studi Kasus pada Ceramah K.H. Anwar Zahid, Ustaz Abdul Somad, dan Ki Joko Goro-Goro" dalam Jurnal JALABAHASA: Jurnal Ilmiah Kebahasaan Vol. 14. No.1. hlm.1-19.

Faisal Sanafiah, 1989. Penelitian Sederhana, Yayasan Asah Asih Asuh, Malang.

I Gusti Ngurah Oka, 1990. Retorika Kiat Bertutur, Yayasan Asah Asih Asuh, Malang

Kusyairi, 2016. Retorika dalam persidangan gugatan percerian suami istri di Pengadilan Agama Pamekasan, Jurnal Komposisi, hal 92 Vol 1 Nomor 2, ISSN 25412868, FKIP Universitas Madura. Pamekasan

Kusyairi Dkk, 2020. Penggunaan bahasa atau dialek Masyarakat dusun Malangan Pademawu Timur Pamekasan, Jurnal Fikrotuna, hal 1260, Vol 10 Nomor 2 P-ISSN 
Volume 2, Nomor 2, Juli 2020

ISSN 2655-3031 (P), 2655-7851 (O)

2441-240, e-ISSN 2477-5622. STAI

Al-Khairat, Pamekasan.

Shelton, Ken, 2002, A New Paradigma of

Leadership, P.T. Elex Media

Komputindo, Jakarta.

Sugiyono, 1998, Metode Penelitian

Administrasi, Alfabeta, Bandung.

Sujanto, Agus, 2006. et. al. Psikologi Kepribadian. Jakarta : Bumi Aksara, 